\title{
O invencível exército de Hitler: propaganda de guerra alemã e imprensa periódica em Santa Catarina, durante a Segunda Guerra Mundial
}

\author{
Wilson de OLIVEIRA NETO ${ }^{1}$
}

Resumo:

O objetivo deste artigo é analisar a propaganda de guerra alemã veiculada na imprensa catarinense durante a Segunda Guerra Mundial, por meio do estudo das fotografias de guerra publicadas nos jornais $O$ aço e Planalto, do município de São Bento do Sul. Como outras cidades de colonização alemã em Santa Catarina, o conflito chegou a São Bento do Sul, inicialmente, por meio da imprensa, que até 1942 publicou exclusivamente fotografias fornecidas pela agência alemã RDV. Após a coleta e a contextualização das fotografias, constatou-se que, em seu conjunto, as fotografias publicadas sugeriram tratar-se de um exército moderno, profissional e invencível. As mensagens contidas nessas imagens foram reforçadas pelas legendas em português, também fornecidas pela RDV. Com a entrada do Brasil na guerra, em meados de 1942, ao lado dos Aliados, a publicação de material alemão cessou e deu lugar a imagens, notícias e reportagens fornecidas pelos Estados Unidos, pelas agências, tais como a Interamericana e o Serviço de Informações do Hemisfério $(\mathrm{SIH})$.

Palavras-chave:

Imprensa. Fotografia. Propaganda de guerra. Segunda Guerra Mundial.

\section{The invencible Hitler's Army: German war propaganda and press in Santa Catarina State, during World War II}

\begin{abstract}
:
The objective of this article is to analyze the propaganda of German war published in the press during the Second World War, through the study of the war photographs published in the newspapers $O$ Aço e Planalto, of the municipality of São Bento do Sul. Like other cities of German colonization in Santa Catarina, the conflict reached Sao Bento do Sul, initially through the press, which until 1942, exclusively published photographs provided by the German agency RDV. After collecting and contextualizing the photographs, it was found that, on the whole, the published photographs suggested a modern, professional and invincible army. The messages contained in these images were reinforced by the Portuguese subtitles, also provided by the RDV. With the entry of Brazil into the war in mid-1942, along with the Allies, the publication of German material ceased and gave rise to the images, news and reports provided by the United States, through agencies such as the Interamericana and the Serviço de Informações do Hemisfério (SIH).
\end{abstract}

Keywords:

Press. Photography. War propaganda. WWII.

\section{El invencible ejército de Hitler: propaganda de guerra alemana y prensa periódica en Santa Catarina, durante la Segunda Guerra Mundial.}

\begin{abstract}
Resumen:
El objetivo de este artículo es analizar la propaganda de la guerra alemana ventilado en la prensa de Santa Catarina durante la Segunda Guerra Mundial, por medio del estudio de las fotografías de guerra publicadas en los periódicos $O$ aço e Planalto, del municipio de São Bento do Sul. Como otras ciudades de colonización alemana en Santa Catarina, el conflicto llegó a São Bento do Sul, inicialmente, atreves de la prensa, que hasta 1942, publicó exclusivamente fotografías suministradas por la agencia alemana RDV. Después de colectar y contextualizar las fotografías, se constató que, en su conjunto, las fotografías publicadas mostraban un ejército moderno, profesional e increíble. Los mensajes que contenían estas imágenes fueron reforzados con los avisos en portugués, también suministrados por la RDV. Con el ingreso de Brasil a la guerra, a mediados de 1942, del lado de los aliados, la publicación de material alemán paró y dio paso a las imágenes, noticias y
\end{abstract}

\footnotetext{
${ }^{1}$ Doutorando em Comunicação e Cultura na ECO/UFRJ. Docente no curso de História da Universidade da Região de Joinville - Univille. E-mail: wilson.o@univille.br.
} 
reportajes suministrados por Estados Unidos, mediante agencias, tales como Intermaericana y el Serviço de Informações do Hemisfério (SIH).

Palabras clave:

Prensa. Fotografía. Propaganda de la guerra. Segunda Guerra Mundial.

\section{Introdução}

A Segunda Guerra Mundial foi um conflito militar internacional ocorrido entre 1939 e 1945. Ela envolveu duas coalizações de países, os Aliados (Estados Unidos, França, Grã-Bretanha e União Soviética) e o Eixo (Alemanha, Itália e Japão). O conflito durou seis anos, com batalhas e campanhas travadas e promovidas em diversos lugares do mundo. Porém, os principais teatros de operações da Segunda Guerra Mundial estavam localizados na Europa e no Extremo Oriente (BEEVOR, 2015).

É consenso entre historiadores, tais como Antony Beevor (2015) e Eric Hobsbawm (1995), que as causas da Segunda Guerra Mundial, desencadeada em 1939, com a invasão alemã à Polônia, estão relacionadas com o expansionismo alemão na Europa, iniciado com a nomeação de Adolf Hitler ao cargo de chanceler da Alemanha, em 1933, e a incapacidade dos governos francês e inglês em contê-lo. Porém, arriscamos afirmar que, conforme o conflito espalhou-se pelo mundo, múltiplas causas foram adicionadas às já citadas, o que tornou a Segunda Guerra Mundial um conflito mundial, porém fortemente influenciada por circunstâncias nacionais e regionais.

Em sua síntese sobre o século passado, Ian Kershaw (2016, p. 353) afirma que, para milhões de europeus, "a Segunda Guerra Mundial [...] foi o mais perto que chegaram do inferno na terra". Ele explica que a destruição provocada pelo conflito provocou o colapso da civilização europeia. Reinhart Koselleck (2014) vai ao encontro desse autor, quando interpreta a Segunda Guerra Mundial como uma guerra total em todos os sentidos, que anulou as diferenças entre civis e militares, alterou os papéis sociais e marcou indelevelmente as experiências e as memórias dos sujeitos afetados pelo conflito.

Nessas circunstâncias, as comunicações foram fundamentais tanto para as operações militares quanto para a mobilização da opinião pública. Junto às forças combatentes dos Aliados e do Eixo marcharam cinegrafistas, fotógrafos e jornalistas que, conscientemente engajados ou vigiados pelas censuras militares, produziram diversas imagens e matérias a respeito do conflito em curso que, distribuídas nacional ou internacionalmente, contribuíram para os esforços de guerra dos países beligerantes, na forma de propaganda de guerra (WELCH, 2002). 
O Brasil entrou no conflito em 31 de agosto de 1942, quando o governo brasileiro declarou guerra contra a Alemanha e a Itália, em resposta aos ataques de submarinos do Eixo contra navios da Marinha Mercante brasileira, iniciados durante o primeiro semestre daquele ano, após o país romper suas relações diplomáticas com as potências do Eixo, em fevereiro de 1942, em solidariedade interamericana aos Estados Unidos, atacados por uma força-tarefa japonesa em dezembro de 1941, no Havaí (PEREIRA, 2015).

Porém, desde 1939, a guerra fazia parte do cotidiano brasileiro, especialmente, pelos meios de comunicação e pela propaganda veiculada pelas potências beligerantes no Brasil. Mesmo sob o forte controle do Departamento de Imprensa e Propaganda (DIP), jornais e revistas publicaram matérias e imagens sobre a Segunda Guerra Mundial, fornecidas por agências de notícias internacionais, tais como o British News Service (Inglaterra), a International News Photo (Estados Unidos), a RDV (Alemanha) e o Serviço de Informações do Hemisfério (Estados Unidos). Suas sucursais estavam localizadas na cidade do Rio de Janeiro, na época Distrito Federal. De lá, distribuíram clichês, fotografias e matérias sobre o conflito para diversos periódicos de grandes e pequenas cidades, tais como São Bento do Sul, situada no nordeste de Santa Catarina.

Figura 1 - Sargento do Exército dos Estados Unidos checando a identificação de prisioneiro alemão.

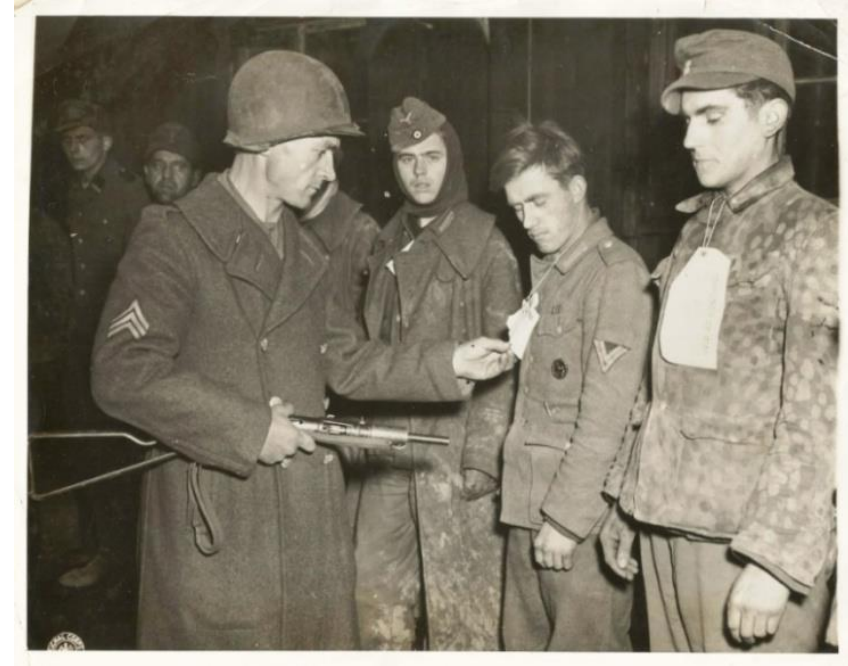

Fonte: Coleção do autor.

A Figura 1 é um exemplo de fotografia que foi fornecida à imprensa brasileira durante a guerra. Originalmente, a fotografia foi feita pelo US Army Signal Corps e distribuída no Brasil pelo Serviço de Informações do Hemisfério. Nos versos das imagens 
foram aplicados carimbos que identificavam as agências que forneceram as fotografias, bem como foram fixadas tiras de papel com textos em português, usados como legendas das fotografias quando publicadas em jornais ou revistas. No caso da agência RDV, conforme mostra a Figura 2, a publicação era gratuita, porém, em contrapartida, era solicitado o envio de um comprovante da publicação da fotografia.

Figura 2 - Aspecto de uma etiqueta de identificação com legenda, fornecida pela RDV.

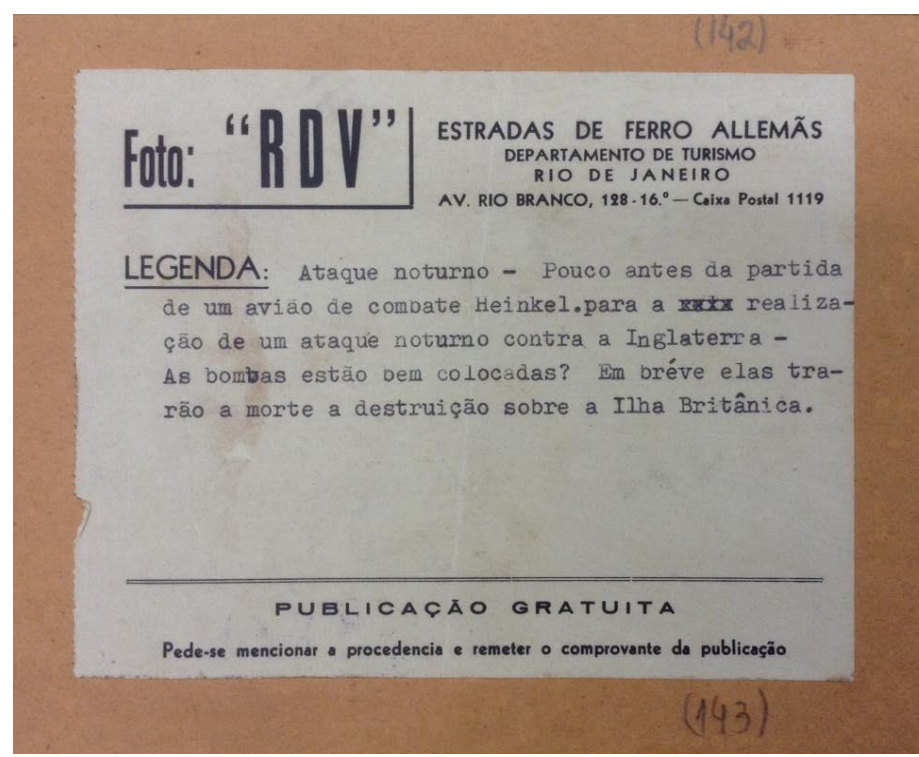

Fonte: Coleção Arquivo Histórico de Joinville (AHJ).

Em suas investigações sobre a fotografia contemporânea, Teresa Bastos e Victa de Carvalho (2012) constataram que os dispositivos fotográficos são, no presente, um meio privilegiado de experimentação do real. Devido ao seu poder de fabulação, os papéis e as funções sociais da fotografia estão a ser ressignificados, tendo como pano de fundo o desenvolvimento das tecnologias e as relações entre as teorias e as práticas fotográficas.

Para a História, a fotografia como fonte histórica está vinculada a essa capacidade de fabulação, de criação de realidades e ficções, conforme defende Boris Kossoy (2009). Para ele, desde o seu surgimento, em meados do século XIX, a fotografia está submetida aos mais variados usos dirigidos, a exemplo da propaganda de guerra, veiculada na imprensa periódica de uma pequena cidade brasileira.

Vilém Flusser (2017) afirma que toda imagem é uma mensagem. Ela tem um emissor e procura por um receptor. Interessa para este trabalho decifrar essa mensagem, através do exame das fotografias acerca do esforço de guerra alemão, publicadas na imprensa periódica. Até o rompimento das relações diplomáticas entre o Brasil e as potências do Eixo e a declaração brasileira de guerra contra a Alemanha e a Itália, foi farta 
a distribuição de material de propaganda do regime nacional-socialista e do esforço de guerra alemão, especialmente nas regiões de colonização alemã no Sudeste e Sul brasileiros (PERAZZO, 1999; TOTA, 2000).

A mídia brasileira da época estava sob forte controle do Estado por meio do Departamento de Imprensa e Propaganda (DIP), criado em 1939, no contexto do Estado Novo (1937 - 1945). Em seu trabalho sobre o DIP, Silvana Goulart (1990) constatou que a publicação de imagens e matérias sobre a Segunda Guerra Mundial teve de atender as diretrizes do governo de Getúlio Vargas. Contudo, como afirma Tania Regina de Luca (2008, p. 158), os jornais são um "espaço privilegiado de luta simbólica". Portanto, fundamentais para os esforços de guerra das potências do Eixo, em particular, a Alemanha, cujas relações diplomáticas com o Brasil, entre 1937 e 1942, foram marcadas pela descontinuidade e mais por pragmatismo que ideologia (RAHMEIER, 2009).

\section{São Bento do Sul em tempo de guerra}

São Bento do Sul está localizado no nordeste do Estado de Santa Catarina, próximo a Joinville, Campo Alegre e Rio Negrinho. Atualmente, o município tem uma população estimada em 82.842 pessoas, distribuídas em uma área de 501, $634 \mathrm{~km}^{2}$, segundo dados de 2018 do Instituto Brasileiro de Geografia e Estatística (IBGE). As origens de São Bento do Sul estão situadas em uma antiga colônia agrícola predominantemente alemã, fundada na região em 23 de setembro de 1873.

Como as demais cidades ligadas à colonização alemã no Sul do Brasil, a Segunda Guerra Mundial chegou cedo a São Bento do Sul e, especialmente, após a entrada do país no conflito. Nesse sentido, é importante mencionar os estudos produzidos sobre Santa Catarina, tais como os trabalhos de Marlene de Fáveri (2004) e Wilson de Oliveira Neto e Sandra Pachoal Leite de Camargo Guedes (2002). Especificamente sobre São Bento do Sul, há o estudo pioneiro realizado por Carlos Augusto Campestrini (2008).

De acordo com esse autor, a declaração brasileira de guerra foi recebida na cidade, na época chamada de Serra Alta, com manifestações públicas de apoio patriótico ao governo, como o exemplo de uma campanha para arrecadação de fundos para a aquisição de um avião militar. A “Campanha do Avião Vingador" arrecadou o total de mais de 30 contos de Réis, valor este enviado para o Ministério da Guerra, no Rio de Janeiro.

Campestrini (2008) também constatou o recrudescimento das leis de nacionalização e o fechamento das principais entidades teuto-brasileiras de São Bento do Sul: a Sociedade 
de Atiradores "23 de Setembro" e a Sociedade Literária São Bento, ambas fundadas durante o final do século XIX. O contexto de guerra no município também foi marcado pelo envio de dezesseis cidadãos-soldados à Força Expedicionária Brasileira (FEB), cujos efetivos participaram de operações militares na Itália, entre 1944 e 1945.

A circulação de imagens e notícias sobre o conflito em curso também foi um dos reflexos da guerra no município, especialmente, quando são considerados os contextos de guerra total e de recrudescimento dos discursos e das medidas de nacionalização no Sul do Brasil. A imprensa foi um dos meios pelos quais a guerra se tornou mais próxima do cotidiano dos habitantes de Serra Alta. Nos jornais foram publicadas cartas, fotografias, frases cívicas e reportagens sobre as batalhas e as campanhas do conflito em suas diversas frentes de combate e as atividades locais acerca do esforço de guerra.

Entre 1939 e 1945, foram publicados em São Bento do Sul dois jornais, $O$ aço e Planalto. O primeiro foi lançado em $1^{\circ}$ de setembro de 1936. Seu proprietário foi Ernesto Venera dos Santos, escritor, empresário e político local, proprietário da Livraria Santos, cujo prédio localizava-se no Centro da cidade. Inicialmente, o jornal era bilíngue, alemão e português, e quinzenal. Mais tarde, tornou-se um semanário. Em 1943, a assinatura anual do jornal custava 15 Cruzeiros.

Até a instalação do Estado Novo, em novembro de 1937, $O$ aço foi um periódico vinculado à Ação Integralista Brasileira (AIB). Fundada pelo escritor modernista Plínio Salgado (1895 - 1975) em 1932, a AIB foi um partido político inspirado no Fascismo. Foi o primeiro partido político de massa e com alcance nacional, diferente dos partidos republicanos estaduais que protagonizaram o cenário político brasileiro durante a Primeira República (1889 - 1930). Hélgio Trindade (1979) informa que, no seu auge, a AIB contou com um total de meio milhão de filiados. Segundo o autor, a Ação Integralista Brasileira surgiu em um contexto de radicalização política no Brasil, com ênfase nas ideias "de direita" e da unificação de movimentos políticos similares em torno do próprio Integralismo. Nesse sentido, conclui Trindade (1979), em sua época, a AIB foi um principal partido político de extrema-direita no Brasil.

Durante o Estado Novo, as edições de $O$ aço foram censuradas pelo Capitão Athanasio de Freitas, na época, delegado de política local, pois, em São Bento do Sul, não existia uma representação formal do DIP, cabendo, então, ao delegado de política a vigilância sobre os meios de comunicação locais, conforme informação obtida junto à equipe do Arquivo Histórico de São Bento do Sul. 
Anos mais tarde, em 24 de outubro de 1944, foi lançado o jornal Planalto, que substituiu $O$ aço. Publicado somente em português, o periódico era propriedade de Joaquim de Salles, sendo redator o Capitão Osmar Romão da Silva. Sob o registro número 14.236 no DIP, Planalto foi um jornal governista. O historiador José Kormann (2006) informa que Salles e Silva foram prefeitos municipais, respectivamente, entre 1939 e 1942, 1945 e 1947. Em seu número de lançamento, afirmou ser a continuação, em "nova fase", de $O$ aço, independente, defensor das causas justas, porém sem ser "jacobino", isto é, radical, e guiado pelo ideal da unidade nacional (PLANALTO, 1944).

Foram coletadas nos jornais $O$ aço e Planalto um total de cinquenta e cinco fotografias, entre 1941 e 1945. Elas não seguiram um design jornalístico específico. As páginas em que os clichês foram impressos variaram ao longo das edições publicadas. Além disso, essas imagens foram publicadas isoladamente. Isto é, não foram integradas às demais matérias escritas a respeito do conflito em curso. No máximo, elas eram acompanhadas de uma legenda que vinha junto à fotografia fornecida pela agência. Ocorreu o fato também de mais de uma fotografia ser publicada por edição, juntas ou em páginas distintas. A qualidade das imagens impressas variou entre "boa" e "ruim".

A ausência de uma regularidade das imagens coletadas dentro de um determinado design jornalístico chamou a atenção. Como explica Eduardo Nunes Freire (2009), os conteúdos escritos e visuais de um jornal estão organizados conforme um dispositivo, cuja articulação confere a esses conteúdos coerência e coesão, identidade e poder de convencimento perante seu público leitor; especialmente, quando se trata de um período de afirmação, legitimação e manutenção de uma autocracia no Brasil e de um conflito mundial em curso, cuja mobilização da opinião pública foi fundamental para os esforços de guerra. Essa característica a respeito do uso das fotografias nos periódicos examinados vai ao encontro do tipo de design jornalístico da época: impressão artesanal, poucos recursos gráficos e tipografia restrita e com poucas famílias de letras (FREIRE, 2009).

\section{O invencível exército de Hitler}

O início da Segunda Guerra Mundial na Europa, em $1^{\circ}$ de setembro de 1939, foi marcado pela ofensiva alemã contra a Polônia, com uma campanha militar orientada pela doutrina da "Guerra-Relâmpago", a Blitzkrieg. A guerra começou às 4 horas da madrugada de $1^{\circ}$ de setembro, quando o couraçado alemão Schleswig-Holstein abriu fogo contra a 
guarnição do exército polonês em Westerplatte, próximo da cidade de Danzig, atual Gdańsk (ZALOGA, 2002).

Após derrotar, ocupar e dividir a Polônia, o passo seguinte da Alemanha foi uma série de campanhas militares que resultou na vitória e na ocupação de diversos países da Europa ocidental pelas suas forças armadas, entre os quais a França. O início da guerra no continente europeu também foi marcado pela ofensiva alemã na imprensa internacional. Por meio das imagens e dos textos produzidos pelos cinegrafistas, fotógrafos e jornalistas recrutados pela Propaganda Kompanien (PK), a imprensa estrangeira recebeu um grande sortimento de cinejornais, fotografias e reportagens sob a ótica alemã. Ao narrar a história do jornalismo de guerra, Phillip Knightley (1978) explica que, comparado com a França e a Grã-Bretanha, a cobertura e a propaganda de guerra alemãs, durante o início da Segunda Guerra Mundial, foram mais eficientes. Dirigido pelo Dr. Joseph Goebbels, o Ministério da Propaganda possuiu um Departamento de Imprensa Estrangeira, sob a chefia de Karl Bonner, responsável pelo fornecimento de material jornalístico para os correspondentes de guerra "neutros", que estavam a trabalhar na capital alemã, Berlim.

Ao contrário das forças armadas da Grã-Bretanha, cuja antipatia explícita com jornalistas e a censura tornaram difícil o trabalho dos correspondentes, o governo alemão se gabava da sua liberdade de notícia, Freie Berichterstattung, informa Knightley (1978). $\mathrm{O}$ autor, porém, também adverte que os jornalistas considerados personae non gratae encontravam obstáculos para a produção de suas matérias e, em casos extremos, poderiam ser presos e acusados de espionagem. No começo da guerra, foi mais "fácil" trabalhar como correspondente na Alemanha que na França ou na Inglaterra.

É possível que esse regime de comunicação mantido pelo governo alemão, por meio do seu Ministério da Propaganda, tenha facilitado o acesso do jornal $O$ aço às fotografias que foram publicadas em suas edições, fornecidas pela RDV. Essa hipótese é reforçada quando Antonio Pedro Tota (2000) menciona a forte concorrência alemã que sofreram as agências de notícias americanas vinculadas ao Escritório de Coordenação de Assuntos Interamericanos, durante a guerra. Segundo o autor: "Os profissionais da área tinham de contra-atacar o serviço de propaganda da Alemanha, presente na América Latina com a Agência Transoceânica Alemã, que fornecia notícias e fotos a preços insignificantes" (TOTA, 2000, p. 55).

A primeira fotografia a respeito do esforço de guerra alemão publicada na coleção examinada é da edição de 2 de agosto de 1941. Já a última apareceu em 27 de setembro de 
1941, em um total de quinze fotografias. Entre o final de 1941 e meados de 1943, não foram publicadas fotos. No caso específico das imagens fornecidas pela RDV, certamente, o rompimento das relações diplomáticas entre o Brasil e a Alemanha, durante o primeiro semestre de 1942 e, em consequência, a declaração de guerra, assinada em 31 de agosto, explicam o corte no fornecimento e nas publicações, que foram substituídas pela agência Interamericana, ligada ao governo dos Estados Unidos.

A maioria das fotografias fornecidas pela RDV publicadas no jornal $O$ aço foi feita no teatro de operações da península Balcânica, também conhecida como Bálcãs, espaço geográfico e histórico situado no sudeste da Europa. O local é dividido em "norte" e "sul" e, atualmente, abrange os seguintes países: Croácia; Bósnia-Herzegóvina; Sérvia; Montenegro; Bulgária; Romênia (norte); Albânia; Macedônia; Grécia; Chipre (sul). Sua história está vinculada às guerras, aos Impérios Austro-Húngaro, Russo e Turco-Otomano, além das religiões católica romana, católica ortodoxa e islamita (ABRIL COLEÇÕES, 2008).

Não foi por acaso a predominância de fotografias sobre as operações de guerra alemãs nos Bálcãs. Após a derrota da Luftwaffe na Batalha da Grã-Bretanha e o cancelamento da Operação Leão Marinho, no final de 1940, o primeiro semestre de 1941 foi marcado pelo desencadeamento da campanha militar alemã na península Balcânica. No contexto de preparação da invasão da União Soviética, conhecida como Operação Barbarossa, a Alemanha teve de garantir o fornecimento de petróleo extraído nos campos petrolíferos de Ploesti, na Romênia, segundo Antony Beevor (2015). Ainda segundo o autor: "Os campos petrolíferos de Ploesti forneceriam combustível para as divisões Panzer, e o exército romeno do marechal Ion Antonescu seria a fonte de soldados" (BEEVOR, 2015, p. 179). Porém, era necessário cautela, pois o sudeste europeu era considerado uma região sob influência soviética e Hitler não pretendia provocar Stalin antes de estar militarmente preparado. O desastre militar italiano na Grécia, no final de 1940, serviu de estopim para o desencadeamento da campanha alemã na região, com a Operação Marita, nome dado ao plano alemão de invasão da Grécia, realizada entre abril e maio de 1941.

A Figura 3 foi publicada na primeira página da edição de 2 de agosto de 1941, do jornal $O$ aço. Com a legenda "Um aspecto da parada realizada perante o General Marechal de Campo List, em Atenas", foram retratados efetivos do exército alemão, uma unidade de ciclistas, em frente ao Marechal de Campo Sigmund Wilhelm Walther List (1880 - 1971) que, na fotografia, encontra-se no centro de um palanque, decorado com a bandeira militar 
da Alemanha. Na página da agência Getty Imagens, há uma fotografia também feita durante o desfile realizado no dia 3 de maio de 1941. Nela, paraquedistas desfilam diante do Marechal, que tem ao lado os Generais Kurt Student (1890 - 1978) e Ferdinand Schörner (1892 - 1973).

Figura 3 - Desfile militar alemão em Atenas.

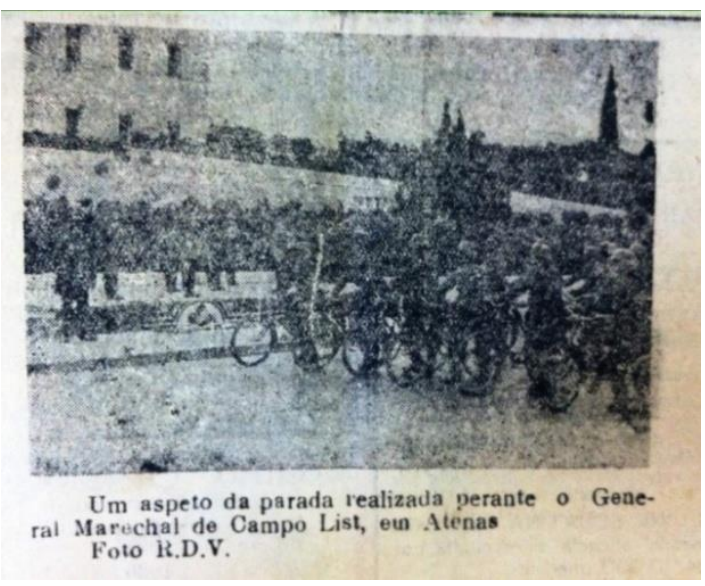

Fonte: $O$ aço, Serra Alta, v. 5, n. 49, p. 1, 02/08/1941 - AHSBS.

$\mathrm{Na}$ mesma edição, porém, na página 4, foi publicada outra fotografia, também relacionada à campanha militar alemã na península Balcânica, em que foi retratado um prisioneiro de guerra esloveno, feito pelos alemães. "Este soldado esloveno foi feito prisioneiro nos primeiros combates fronteiriços travados em 6 de abril último, na Iugoslávia setentrional”, informa a legenda (Figura 4).

Figura 4 - Um prisioneiro de guerra esloveno.

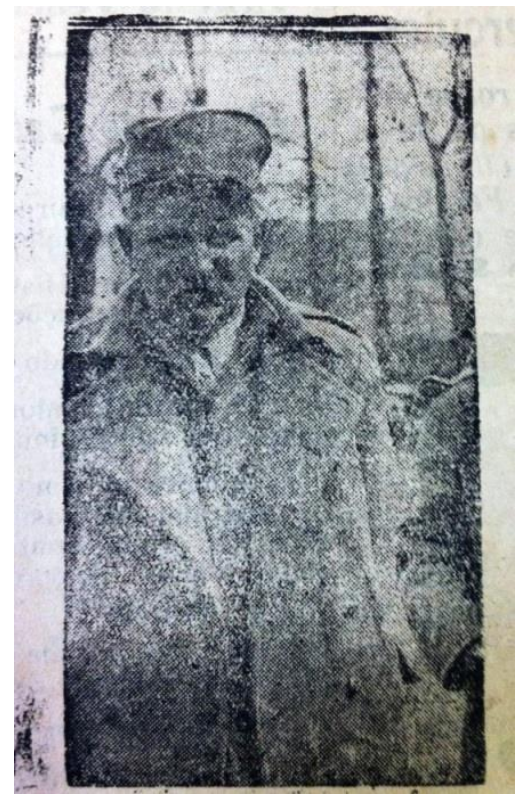

Fonte: $O$ aço, Serra Alta, v. 5, n. 49, p. 4, 02/08/1941 - AHSBS. 
Parte do efetivo alemão que invadiu a Grécia partiu da Iugoslávia, que também foi invadida pelos alemães. Durante a Segunda Guerra Mundial, o governo iugoslavo se posicionou contra os interesses da Alemanha e, após um acordo militar frustrado com a União Soviética, teve seu território invadido e dividido entre os alemães e os países vizinhos aliados do Eixo. Eslovenos e sérvios, na época pertencentes à Iugoslávia, lutaram contra a Alemanha, enquanto os croatas foram seus aliados (BEEVOR, 2015).

Se a data informada na legenda da fotografia está correta, 6 de abril, um Domingo de Ramos, ao mesmo tempo em que o soldado fotografado foi capturado, a capital da então Iugoslávia, Belgrado (hoje, capital da Sérvia), era bombardeada por aviões da $4^{\text {a }}$ Luftflotte da força aérea alemã. Segundo Beevor (2015), em dois dias, a maior parte de Belgrado foi destruída, com um número de mortos situado entre 1.500 e 30 mil pessoas. Ainda sobre a fotografia representada pela Figura 4, ela é um recorte ampliado da fotografia original, conforme sugere um braço direito que é possível ver no canto direito da imagem, situado um pouco à frente do prisioneiro retratado, cuja aparência alquebrada e cansada, com olheiras profundas e olhar vago de quem vivenciou um tempo intenso de combate, justifica tal manipulação do original, prática comum no fotojornalismo da época.

$\mathrm{Na}$ interpretação deste trabalho, o recorte feito na fotografia original produziu uma imagem, cujo impacto entre seu público alvo seria muito maior, ao reforçar aquilo que Zerwes (2016) definiu como "eloquência visual". Algo completamente coerente com o trabalho confiado aos efetivos da PK, cujos textos escritos e visuais deveriam "influenciar o curso da guerra através do controle psicológico do estado de espírito na pátria, no exterior, no front e no território inimigo" (DER PROPAGANDATRUPPE... apud KNIGHTLEY, 1978, p. 280).

A Figura 5 é outro exemplo de fotografia, cujo original foi manipulado pela equipe da PK antes de ser distribuída. Ela foi publicada na primeira página da edição de 9 de agosto. "Soldados do Reich na Acrópole", informa a legenda. Nela, três militares alemães foram fotografados, de baixo para cima, tendo como cenário as cariátides do templo de Erecteiron, consagrado aos deuses Atena e Posídon, cujas ruínas estão localizadas na Acrópole da cidade de Atenas, na Grécia. 
Figura 5 - Soldados alemães na Acrópole de Atenas.

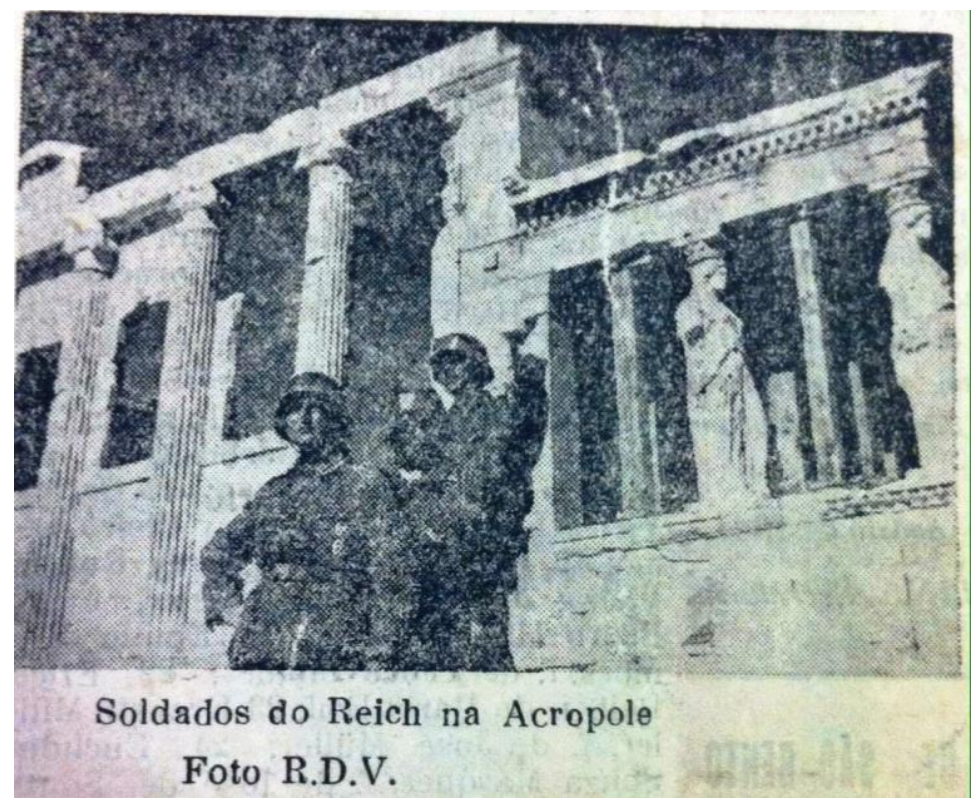

Fonte: $O$ aço, Serra Alta, v. 5, n. 50, p. 1, 09/08/1941 - AHSBS.

O autor da fotografia foi um fotógrafo identificado como "Jesse". O negativo original está sob a guarda do Arquivo Federal da Alemanha (Bundesarchiv), situado na cidade de Koblenz. Uma cópia, contudo, está disponível para consulta pública no banco de imagens da PK mantido pela Wikimedia Commons. Ao comparar a imagem publicada na edição de $O$ aço com a fotografia original (Figura 6), constatou-se que a fotografia publicada sofreu um pequeno recorte e uma ampliação, que reforçaram o protagonismo dos militares fotografados.

Figura 6 - Fotografia feita a partir do negativo original.

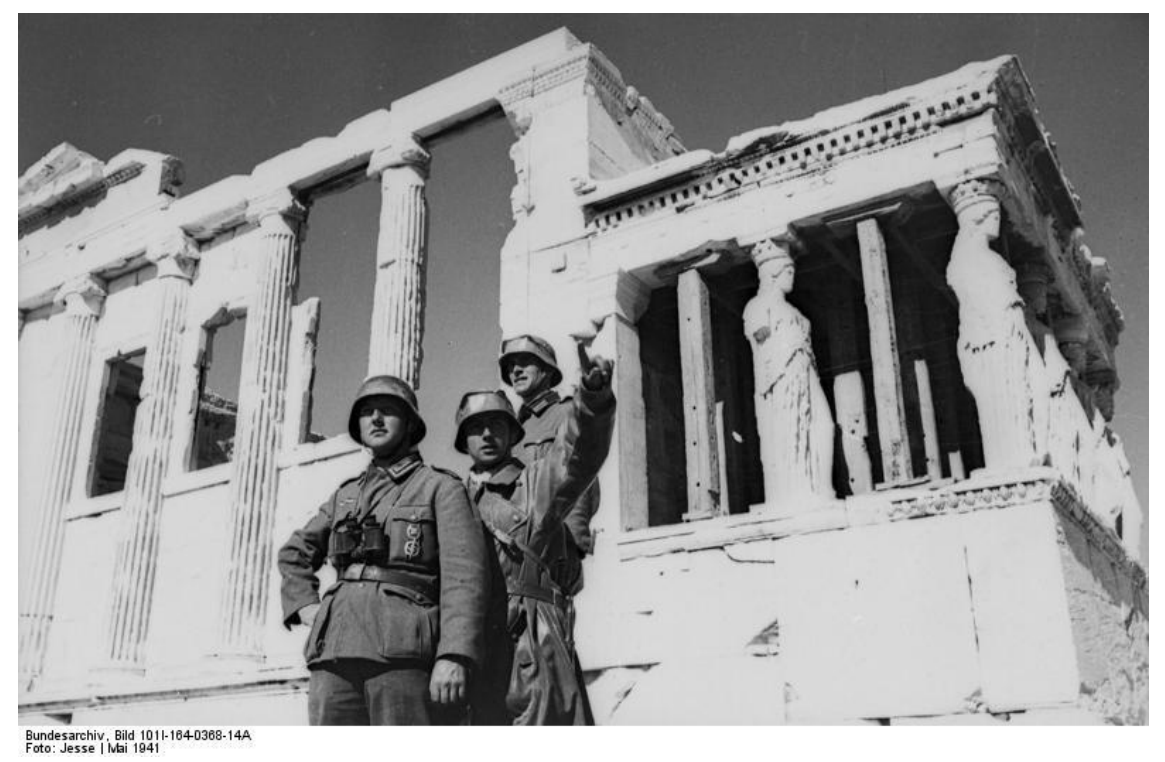

Fonte: Wikimedia Commons. 
$\mathrm{Na}$ mesma edição, foi publicada uma segunda fotografia, também na primeira página do jornal e ao lado dos "soldados do Reich", com a legenda "Reforços para as tropas alemãs sendo desembarcados em um porto grego" (Figura 7).

Figura 7 - Desembarque de reforços alemães em um porto grego.

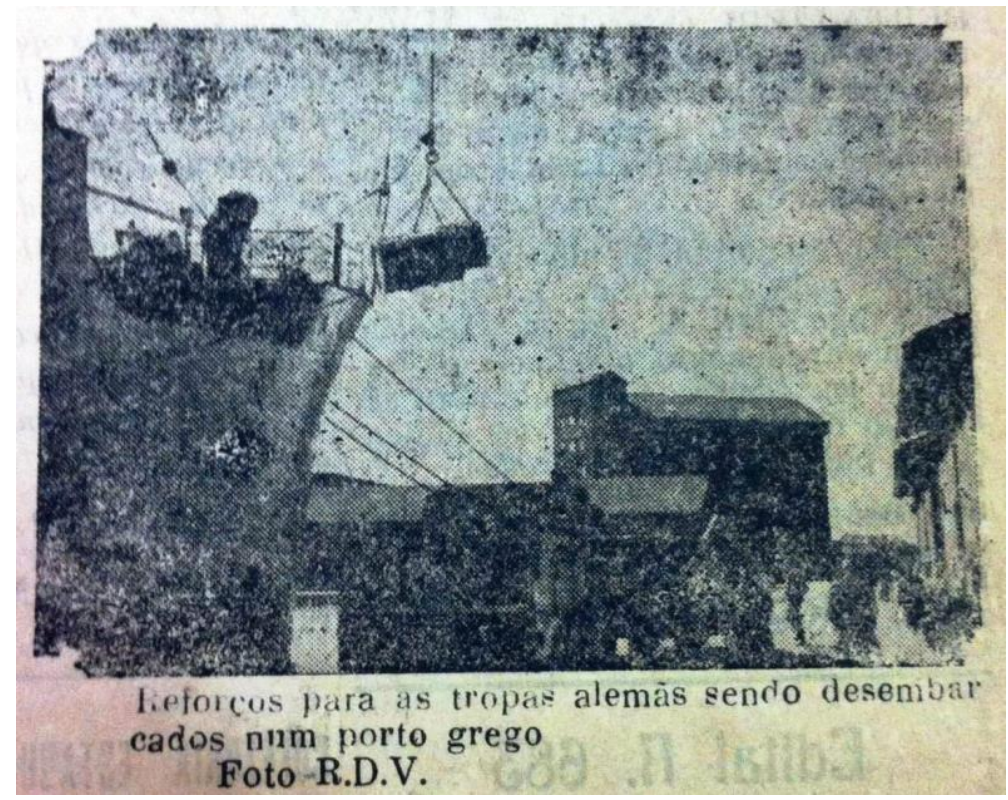

Fonte: $O$ aço, Serra Alta, v. 5, n. 50, p. 1, 09/08/1941 - AHSBS.

No fim de abril de 1941, as primeiras forças combatentes alemãs entraram em Atenas. No dia 26, uma enorme bandeira militar alemã foi hasteada sobre as ruínas da Acrópole. Segundo informam os registros do Bundesarchiv, disponíveis na Wikimedia Commons, o registro fotográfico fora efetuado pelo PK "Jesse" em maio de 1941, no contexto da entrada dos alemães em Atenas. A capitulação da capital grega, contudo, não representou o fim da campanha germânica na Grécia. A Figura 7 alerta que a campanha não acabou, reforçando a imagem da máquina de guerra alemã, formada por soldados profissionais e uma estrutura de logística moderna, eficiente e implacável.

Imagens das operações militares alemãs na Grécia voltaram a ser publicadas na edição de 6 de setembro, conforme mostra a Figura 8. Elas foram impressas na primeira página da edição e retrataram efetivos das brigadas de paraquedistas alemães em ação, durante a batalha pela ilha de Creta, no sul da Grécia, na região do mar de Creta. Suas legendas são: "Paraquedistas alemães" e "Paraquedistas alemães aprontam-se num aeródromo". 
Figura 8 - Paraquedistas alemães em um aeródromo.

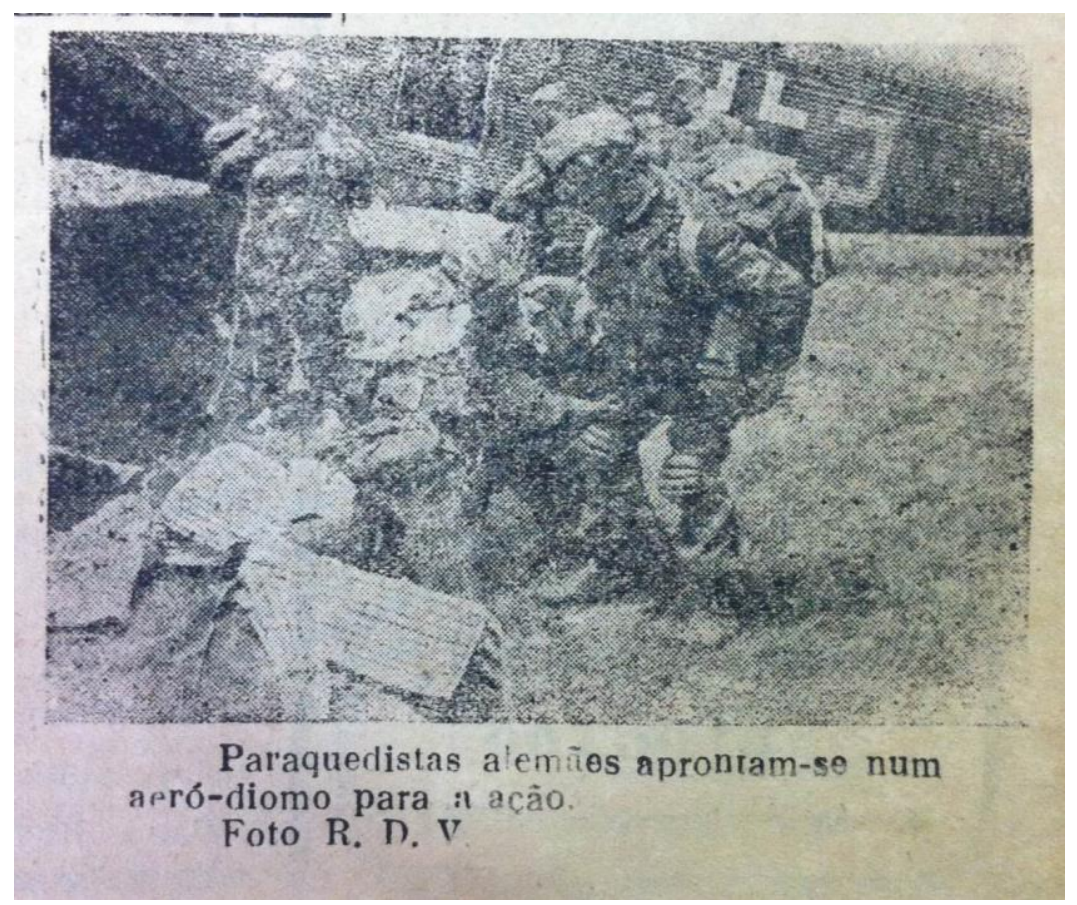

Fonte: $O$ aço, Serra Alta, v. 6, n. 2, p. 1, 06/09/1941 - AHSBS.

É importante destacar que as fotografias publicadas em $O$ aço não seguiram rigorosamente a cronologia da campanha militar alemã nos Balcãs, "indo" e "voltando" no tempo de acordo com as fotografias publicadas, algo contraditório com o Jornalismo, na medida em que a cronologia dos fatos é de sua natureza. É possível que essa falta de rigor cronológico seja o resultado do fornecimento de imagens por parte da RDV ou advir do próprio caráter propagandístico das fotografias para o qual sua eloquência é mais importante que o rigor cronológico.

A Figura 8 foi um dos registros históricos a respeito da Batalha de Creta, travada entre alemães e ingleses entre 20 de maio e $1^{\circ}$ de junho de 1941 . No contexto da campanha alemã nos Bálcãs, conquistar Creta era importante por duas razões: $1^{a}$ ) Impedir que os aliados a usasse como base para ataques aéreos contra os campos petrolíferos de Ploesti, na Romênia; $2^{a}$ ) Fazer com que ela se tornasse uma base para ataques aéreos da força aérea contra objetivos no porto de Alexandria e no canal de Suez, no Egito. "A Luftwaffe queria restaurar o seu prestígio após ser derrotada pela RAF na Batalha da Inglaterra", revela Beevor (2015, p. 190). Daí, a Operação Mercúrio, nome em código do plano alemão de invasão de Creta, estar fundamentada no emprego de tropas aerotransportadas. Não é de espantar, portanto, a produção e a circulação de imagens a respeito dessa operação, como o exemplo da própria Figura 8. 
A Batalha de Creta foi encerrada em $1^{\circ}$ de junho de 1941. A fotografia representada pela figura 8 foi publicada no jornal $O$ aço somente em 6 de setembro. Dois meses depois da vitória alemã. A propaganda de guerra alemã em torno de suas brigadas de paraquedistas foi intensa e veiculada por cartões e selos postais, cartazes, cinejornais, fotografias e publicações diversas, como brochuras e livros. A fotografia publicada na edição de 6 de setembro faz parte desse regime de comunicação, cuja forte eloquência visual reforçou a condição dos paraquedistas como tropa de elite das forças armadas da Alemanha, a Wehrmacht, algo que, de fato, eles foram (QUARRIE, 2001).

Como toda propaganda de guerra, todavia, as fotografias publicadas em $O$ aço não revelaram que a vitória alemã em Creta foi uma "vitória de Pirro" para as forças combatentes aerotransportadas da Wehrmacht. Os alemães tiveram um total de 6 mil baixas, com 146 aeronaves destruídas e outras 156 severamente danificadas. Após Creta, Hitler decidiu nunca mais empregar tropas aerotransportadas em operações de grande escala, ao contrário dos Aliados que, com a derrota sofrida na ilha, promoveram o desenvolvimento de suas próprias brigadas de paraquedistas e demais unidades aerotransportadas, como explica Beevor (2015). Os Fallschirmjäger não saltaram mais, porém sua reputação permaneceu firme e forte na propaganda alemã, como as imagens da RDV sugerem.

A maior parte das fotografias fornecidas pela RDV publicada nas edições analisadas do jornal $O$ aço se refere à campanha alemã na península balcânica. De um total de quinze fotografias coletadas, nove registraram fatos relacionados aos Bálcãs. A conquista da Grécia foi o tema principal, contudo, outros aspectos da campanha também foram divulgados, naturalmente, sob a óptica alemã, como mostra a Figura 9, publicada na edição de 23 de agosto, que afirmou a aliança entre a Alemanha e a Croácia, por meio de uma propaganda comercial, reforçada pela seguinte legenda:

Inestimáveis riquezas em madeira possui a Croácia nas suas antigas florestas. Na Alemanha, encontrou um mercado grande e certo para essa importante matéria-prima. As gigantescas toras são trazidas da floresta de Sebesic para a mais próxima estação de transporte, por veículos de tração animal, de onde são remetidos para a Alemanha por via marítima ou ferroviária. 
Figura 9 - Cooperação comercial entre Alemanha e Croácia.

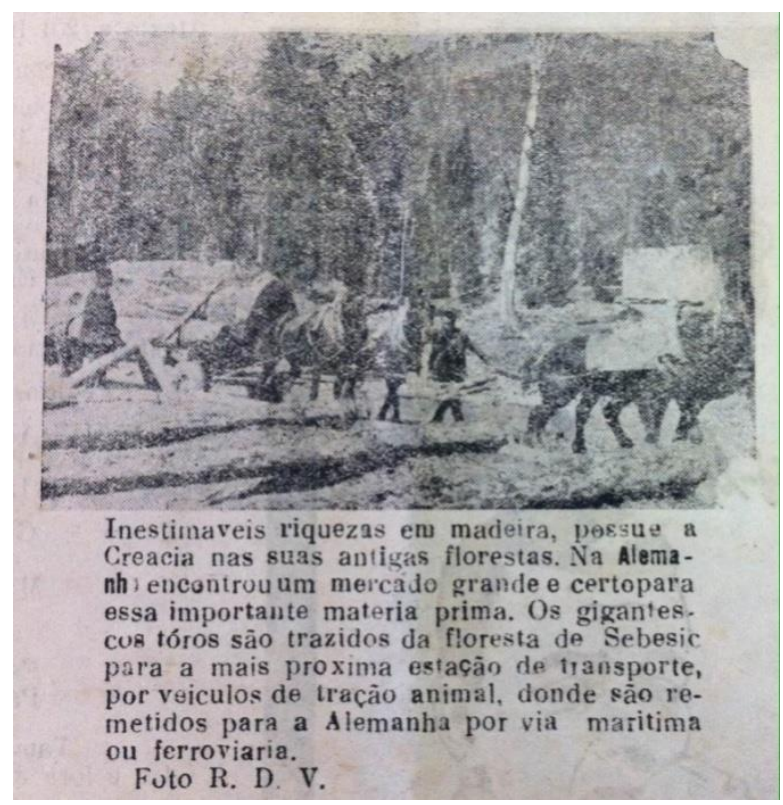

Fonte: $O$ aço, Serra Alta, v. 5, n. 52, p. 4, 23/08/1941 - AHSBS.

A Iugoslávia se rendeu à Alemanha em 17 de abril de 1941. Dias antes, em 10 de abril, foi proclamado o Estado Independente da Croácia, por Slavo Kvaternik, líder de uma facção política denominada Ustaše. Apesar da propaganda veiculada pela RDV, na prática, o Estado Independente da Croácia foi um estado-fantoche da Alemanha na região que restou da antiga Iugoslávia, após sua derrota militar. Reforçar o imaginário de cooperação econômica e militar entre a Alemanha e os seus países aliados nos Bálcãs foi um dos objetivos da propaganda de guerra veiculada.

As seis fotografias restantes são referentes aos seguintes assuntos e lugares: teatro de operações no norte de África - 3 fotos; Marinha de Guerra, Kriegsmarine - 1 foto; avião inimigo abatido - 1 foto; condução de operação militar em lugar não identificado - 1 foto. Chamou atenção a fotografia a respeito do avião inimigo abatido, que pode ser visualizada na Figura 10. A imagem foi publicada na edição de 13 de setembro de 1941, junto a outras duas fotografias publicadas na página 4 do periódico. Com a legenda "Um aparelho britânico abatido pela arma antiaérea do Reich", provavelmente, um avião de caça biplano Gloster Gladiator, a imagem sugere um troféu de guerra. 
Figura 10 - Avião inglês abatido.

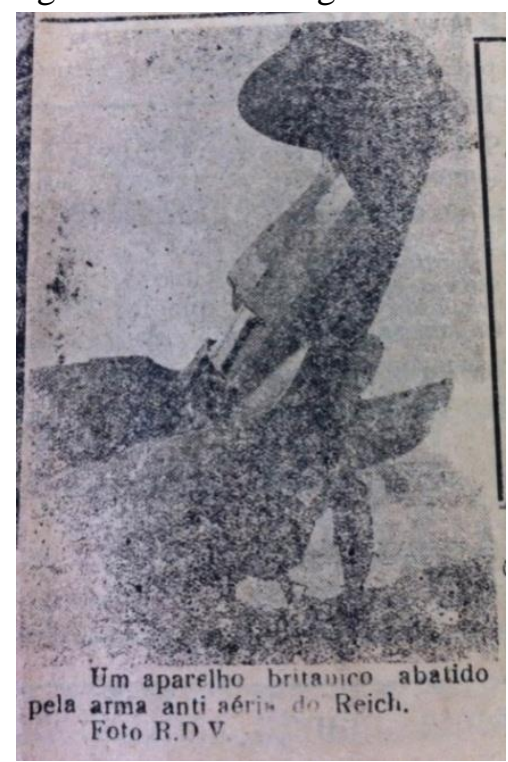

Fonte: $O$ aço, Serra Alta, v. 6, n. 3, p. 4, 13/09/1941 - AHSBS.

Imagens de aeroplanos abatidos, assim como de demais armamentos e equipamentos militares capturados ou destruídos, são recorrentes na propaganda de guerra tanto dos Aliados quanto do Eixo e tinham como objetivo abalar a moral militar inimiga, como mostra a Figura 11. Nela, efetivos das forças terrestres inglesas, provavelmente, no contexto da Batalha da Grã-Bretanha, examinam, sorridentes, um pedaço da fuselagem de um avião alemão abatido. A imagem destaca a insígnia da Luftwaffe e as perfurações provocadas pelo fogo antiaéreo ou a artilharia de um caça inglês responsável pela sua queda.

Figura 11 - Efetivos das forças terrestres inglesas examinam pedaço da fuselagem de um avião alemão abatido.

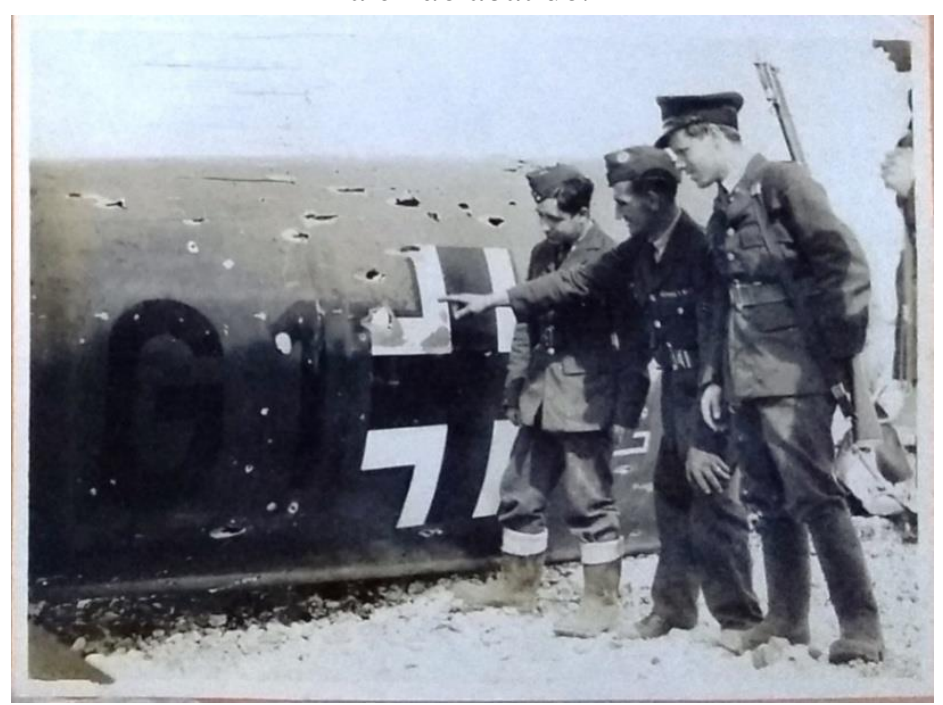

Fonte: Coleção Arquivo Histórico de Joinville - AHJ. 


\section{Considerações finais}

Desde o seu surgimento, a fotografia é apropriada para os mais variados fins, entre os quais a propaganda de guerra. Durante a Segunda Guerra Mundial, ela foi empregada amplamente pelas potências beligerantes, entre as quais a Alemanha que, por meio dos fotógrafos da PK, produziu e distribuiu diversas fotografias das suas forças armadas, batalhas e campanhas militares (KNIGHTLEY, 1978).

Até 1941, por meio da agência RDV, parte dessas imagens foi veiculada pelo jornal $O$ aço, na época, o único em circulação em São Bento do Sul. Em um município de colonização marcadamente alemã, as fotografias publicadas foram além do registro de um conflito em curso e tornaram-se importantes meios de propaganda do esforço de guerra da Alemanha nos territórios do extinto Império Austro-Húngaro, países de onde vieram diversos habitantes de São Bento do Sul.

A entrada do Brasil na guerra em 1942, contudo, cessou a entrada de propaganda de guerra alemã no país. O DIP baniu imagens e matérias sobre o conflito sob a ótica alemã. No lugar do material fornecido pela RDV, fotografias e textos escritos em grande quantidade foram fornecidos à imprensa, naturalmente com o aval do governo de Getúlio Vargas, por agências de notícias vinculadas, principalmente, aos Estados Unidos, tais como a Interamericana e o Serviço de Informações do Hemisfério. Essas agências, por sua vez, estavam subordinadas ao Escritório de Coordenação de Assuntos Interamericanos, peça importante do xadrez político estadunidense na América Latina (LOCASTRE, 2017).

Nessa transição, o esforço de guerra aliado e o paradigma econômico e político dos Estados Unidos tomaram o lugar do invencível exército de Hitler e procuraram atribuir outros sentidos à guerra junto ao público de São Bento do Sul.

\section{Referências}

ABRIL COLEÇÕES. Atlas National Geographic: Europa III. São Paulo: Abril, 2008.

BASTOS, Teresa; CARVALHO, Victa. Apresentação. In: BASTOS, Teresa; CARVALHO, Victa (orgs.). Fotografia e experiência: os desafios da imagem na contemporaneidade. Rio de Janeiro: Walprint Gráfica e Editora, 2012. p. 5 - 15.

BEEVOR, Antony. A Segunda Guerra Mundial. Rio de Janeiro: Record, 2015.

CAMPESTRINI, Carlos Augusto. São Bento do Sul na Segunda Guerra Mundial. São Bento do Sul: JL Ltda., 2008.

FÁVERI, Marlene de. Memórias de uma (outra) guerra: cotidiano e medo durante a Segunda Guerra Mundial em Santa Catarina. Florianópolis: Editora da UFSC, 2004. 
FLUSSER, Vilém. O mundo codificado: por uma filosofia do Design e da Comunicação. São Paulo: Ubu Editora, 2017.

FREIRE, Eduardo Nunes. O design no jornal impresso diário. Do tipográfico ao digital. Revista galáxia, São Paulo, n. 18, p. 291-310, dez. 2009.

GOULART, Silvana. Sob a verdade oficial: ideologia, propaganda e censura no Estado Novo. São Paulo: Marco Zero, 1990 (Onde está a República?).

HOBSBAWM, Eric. Era dos extremos: o breve século XX (1914 - 1991). São Paulo: Companhia das Letras, 1995.

INSTITUTO BRASILEIRO DE GEOGRAFIA E ESTATÍSTICA - IBGE. São Bento do Sul. 2018. Disponível em <https://cidades.ibge.gov.br/brasil/sc/sao-bento-dosul/panorama>. Acesso em: 10 mar. 2018.

KERSHAW, Ian. De volta do inferno: Europa, 1914 - 1949. São Paulo: Companhia das Letras, 2016.

KNIGHTLEY, Phillip. A primeira vítima. O correspondente de guerra como herói, propagandista e fabricante de mitos, da Criméia ao Vietnã. Rio de Janeiro: Nova Fronteira, 1978.

KOSELLECK, Reinhart. Estratos do tempo: estudos sobre história. Rio de Janeiro: Contraponto; PUC-Rio, 2014.

KOSSOY, Boris. Realidades e ficções na trama fotográfica. 4. ed. São Paulo: Ateliê Editorial, 2009.

LOCASTRE, Aline Vanessa. Seduções impressas: a veiculação do paradigma estadunidense no Brasil em tempo de Segunda Guerra Mundial. Curitiba: Editora CRV, 2017.

LUCA, Tania Regina de. A grande imprensa na primeira metade do século XX. In: MARTINS, Ana Luiza; LUCA, Tania Regina de (org.). História da imprensa no Brasil. São Paulo: Contexto, 2008, p. 149 - 175.

OLIVEIRA NETO, Wilson de; GUEDES, Sandra P. L. de Camargo. Medo e desconfiança na "Alemanha brasileira" (1939 - 1945). Caderno de iniciação à pesquisa, Joinville, v. 4, p. $146-151$, nov. 2002.

PEREIRA, Durval Lourenço. Operação Brasil:o ataque alemão que mudou o curso da Segunda Guerra Mundial. São Paulo: Contexto, 2015.

PERAZZO, Priscila Ferreira. O perigo alemão e a repressão policial no Estado Novo. São Paulo: Arquivo do Estado, 1999 (Coleção Teses \& Monografias; v. 1).

PLANALTO. Planalto, Serra Alta, v. 1, n. 1, p. 1, 24 out. 1944. 
QUARRIE, Bruce. Fallschirmjäger: Germanparatrooper 1935 - 1945. Oxford: OspreyPublishing, 2001 (Warrior; v. 38).

RAHMEIER, Andrea Helena Petry. Relações diplomáticas e militares entre a Alemanha e o Brasil: da proximidade ao rompimento. 2009. 390 f. Tese (Doutorado em História) Programa de Pós-Graduação em História, PUCRS, Porto Alegre, 2009.

TOTA, Antonio Pedro. O imperialismo sedutor: a americanização do Brasil na época da Segunda Guerra. São Paulo: Companhia das Letras, 2000.

TRINDADE, Hélgio. Integralismo: o fascismo brasileiro na década de 30. 2. ed. São Paulo; Rio de Janeiro: DIFEL, 1979 (Corpo e Alma do Brasil).

WELCH, David. The Third Reich politics and propaganda. 2. ed. Londres; Nova Iorque, Routledge, 2002.

ZALOGA, Steven J. Poland 1939: the birth of Blitzkrieg. Oxford: Osprey Publishing, 2002 (Campaign).

ZERWES, Erika. A fotografia ícone: imagens de guerra icônicas e a cultura visual contemporânea. Studium 38, Campinas, p. 5 - 24, nov. 2016.

Submetido em: 28.06.2018

Aprovado em: 01.02.2019 